\title{
Random Periareolar Fine-Needle Aspiration
}

National Cancer Institute

\section{Source}

National Cancer Institute. Random Periareolar Fine-Needle Aspiration. NCI Thesaurus.

Code C101266.

A procedure in which a fine needle is inserted around the area of the areola to aspirate

cells from the breast parenchyma and is used to evaluate the short-term risk of developing breast cancer in women with a family history of breast cancer. 